\title{
UNITIZATION AND SECURITIZATION OF PROPERTY INVESTMENT: IMPLICATIONS FOR FUTURE VALUATION
}

\author{
Aluko Bioye Tajudeen ${ }^{1}$, Olaleye Abel ${ }^{2}$ \\ Department of Estate Management,Obafemi Awolowo University,Ile-Ife, Nigeria. \\ E-mail: ${ }^{1}$ btaluko@yahoo.com ; 234-(0)8033378674
}

Received 0408 2005; accepted 06092005

\begin{abstract}
Property investments are now mobile, being tradable securities or listed units (vehicles) comparable to stocks/ shares in the financial market. Hence, the need for valuation to be a counterpart to investment and security analysis. But, current valuation practice in the country has not placed property in a wider economy and the analytical techniques of other markets. The paper therefore demonstrates how current valuation techniques in the property market can meet the needs of investors for listed or tradeable property assets in the country. It also examines the implications on the valuation profession as well as the attendant consequences that are likely to be associated with the quest for change. The study utilizes data from both the Nigerian property and capital markets using simple descriptive, non-statistical, techniques.
\end{abstract}

Keywords: Unitization, Securitization, Property Investment, Valuation Implications.

\section{Introduction}

Real property long has been a significant investment outlet for major institutional investors. And, the resurgence of real estate in securities form, specifically real estate investment trusts (reits), units' trusts and property shares has further heightened the investors' interest in property. This is being so since real property, through unitization and securitization, is a process of turning equity interest in real estate, which is illiquid and lumpy, into tradable securities such as bonds or shares. It further attempts to treat property as part of a wider investment community.

The conversion of property assets into tradable paper securities and the adoption of vehicles based on a unit structure are fairly young financial markets innovations. The concept has its origin in the USA, where Asset-Backed Securities (MBS) were developed in the 1980's to save the thrifts in the savings and loans crisis. In the UK, unitisation vehicles such as Single Asset Property Company (SAPCO), Single Property Ownership Trusts (SPOT) and Property Income Certificates (PINS) were also introduced to facilitate investors to take up the equity interests and directly participate in the rental and capital value performance of a property. In Nigeria, the quest for unitisation and securitisation is slow and young beginning from 1997. The leading lights are the UACN Property Development Company PLC and Stallion Property and Development Company Limited.

The integration of securities and real estate markets has renewed investor interest in how securities markets value publicly held real estate and the management of its productive use. Valuation in the stock market means estimating the value of a stock to a buyer. Pricing is a function which is carried out by buyers, sellers and market makers. In property, however, there are no market makers and, valuation is the practice of estimating market price subject to a series of ridiculous assumptions. (Baum and Crosby, 1995). Many assert that stock prices are facts, whereas real estate appraisal values are opinions, largely because a transaction at that price could confidently be executed for the former but not the latter. In stock market, being an efficient medium, price is the best estimate of underlying value. And, an efficient market is one where prices fully 
reflect all known information quickly and accurately. Therefore, once commercial property assumed a place alongside equities, bonds and cash in the portfolios of the investing institutions, reliable valuation information is fundamental to investment management and is of particular concern in institutional real estate. Property valuation could no longer be seen as brick and mortal valuation, but rather as investment analysis, a counterpart to security analysis. Thus, most investment managers will be more comfortable with valuers whose investment analysis and performance measurement techniques utilised in the securities valuation or other asset markets would be applied to real estate. Besides, property advice to business needs to be linked to the core functions of the business and valuers need to appreciate the implications that property has for business processes. Nevertheless, the property market in the country has failed to incorporate analyses, which have been developed and applied elsewhere. Property investment has been focused at the level of the individual property with an emphasis on physical and locational characteristics rather than at a more aggregate portfolio level. This paper is intended to fill the gap so that the estate surveyor and valuer will be armed with a full set of tools when asked to provide input into a situation requiring business valuation related directly or indirectly to equities, bonds and other tradable securities.

The discussion which follows present a case study, identifies reasons for securities' valuation, explains methods and procedures of valuation as well as the attendant consequences of the financial innovation on the valuation profession in the country.

\section{Case study: UACN property development company (UPDC) PLC}

UACN Property Development Company Plc (UPDC) is a property investment company incorporated on 6th October 1997 and, the first to be listed on the Nigerian Stock Exchange in November 1998.

The company's objective is to acquire, develop and provide high quality accommodation for corporate bodies and high networth individuals. The corporate strategy is to provide a firm foundation on which the company will safely enhance the value and quality of its assets for the benefit of all its stakeholders.

The company is owned $46 \%$ by UAC of Nigeria Plc and $54 \%$ by other Nigerian shareholders, which include individuals and trustees, some corporate bodies as well as directors and connected persons. As at year
2000 , the total value of portfolio is N6, 667, 805, 000 with a gross income on portfolio (investment properties only) of N349, 126, 000 and rental income growth rate of $24.8 \%$. The portfolio has residential, commercial and industrial properties concentrated mainly in Lagos, Abuja and Port - Harcourt. The value of portfolio by property type as at December 2002 is $42.7 \%$ to commercial, $53.6 \%$ residential and $3.7 \%$ rest house.

Creating a publicly quoted company has conferred greater flexibility and freedom on the property outfit to manage its portfolio for maximum returns. Through this scheme, UPDC have been recording better returns on asset than hitherto and consequently enhanced returns on investment to shareholders. For instance, evidence from the data available in table 1 indicates that there has been a steady increase in turnover, profit before and after tax, net assets per share and earnings per share since the company was quoted in 1998 on the stock exchange up to 2001. In the year 2001, the company made a turnover of over N1.4 billion and a profit before tax (PBT) of N583 million. These represent increases of $102 \%$ and $194 \%$ on turnover and PBT, respectively in 2000 over 1999 results. Comparing this with the year 2001, PBT was N694.5 million, an increase of $19 \%$ over 2000 while Profit After Tax (PAT) of N566.7 million was an increase of $16 \%$. In addition to the above, the net assets per share and earnings per share have been improving from N4.80 and N0.13 respectively in 1998 to N6.69 and N0.57 respectively in 2001. The share price for the company in 2001 was N4.62 per share, an increase of $204 \%$ over the 2000 figure (N0.52). In the light of the unsettled business and economic environment in the years under review, the results are encouraging.

From the foregoing we could adduce that the mode of operation and the efficiency of the market affects the turnover, PBT, PAT, earnings per share, net assets per share and, consequently, the value of the business enterprise. It, therefore, shows that if property market is not divorced from the securities and equities markets, through unitisation and securitisation, it would make real estate a liquid investment, capable of adding value, more efficient operators and, offer diversification. It also enhances performance measurement and optimum asset allocation. Valuers must note that property is an integral or major factor in many business decisions and therefore property advice needs to be set in a business context. In the year 2001, for example, at UPDC, commercial properties contributed N143.8 million (year $2000-$ N127.6 million) to turnover while residential properties contributed N222.8 million (year 2000 - 
Table 1. Financial highlights (UPDC) $(1998-2001)$

\begin{tabular}{|c|c|c|c|c|c|c|c|}
\hline YEAR & $\begin{array}{c}1998 \\
N^{\prime} 000\end{array}$ & $\begin{array}{c}1999 \\
\text { N'000 }\end{array}$ & $\begin{array}{c}\% \\
\text { CHANGE }\end{array}$ & $\begin{array}{c}2000 \\
N^{\prime} 000\end{array}$ & $\begin{array}{c}\% \\
\text { CHANGE }\end{array}$ & $\begin{array}{c}2001 \\
\text { N'000 }\end{array}$ & $\begin{array}{c}\% \\
\text { CHANGE }\end{array}$ \\
\hline Turnover & 367,813 & 698,885 & 90 & $1,411,903$ & 102 & $1,722,014$ & 22 \\
\hline Profit Before Tax & 171,068 & 198,381 & 16 & 582,980 & 194 & 699,476 & 19 \\
\hline Taxation & $(39,125)$ & $(43,698)$ & 12 & $(94,492)$ & 116 & $(127,721)$ & 35 \\
\hline Profit After Tax & 131,943 & $(154,692)$ & 17 & 488,488 & 216 & 566,755 & 16 \\
\hline Dividend & $(120,000)$ & $(140,000)$ & 17 & $(300,000)$ & 114 & $(350,000)$ & 17 \\
\hline Net Asset Per Share (N) & 4.80 & 6.29 & 31 & 6.53 & 4 & 6.69 & 2 \\
\hline Earnings Per Share - Basic (N) & 0.13 & 0.15 & 16 & 0.48 & 220 & 0.57 & 16 \\
\hline Dividend Per Share (N) & 0.12 & 0.14 & 17 & 0.30 & 114 & 0.35 & 17 \\
\hline Share Price as at $31^{\text {st }}$ Dec. $(\mathrm{N})$ & - & - & - & 0.52 & - & 4.62 & 204 \\
\hline
\end{tabular}

Source: Author's Survey, May 2003

N221.5 million). This also shows that the relationship between the private values and public values of real estate is important to investors seeking undervalued firms, looking for firm restructuring opportunities, and to both the professional and academic in measuring the contributions of liquidity and management value.

In contradistinction to the above, it is also observed that, even, where a company is not fully a property business, whether or not publicly quoted, property constitutes and contributes a percentage of total assets and turnovers respectively. Evans, French and O'Roarty (2001) comment:

"From the viewpoint of an operational company, property fulfils two roles. First, it provides space from which the business can operate. In this role it is simply one of the three factors of production. The other factors are money (capital) and people (labour). As a factor of production it will be viewed as a cost to the company - that cost being deducted, in the case of leasehold properties, as rent paid and, in the case of freeholds, as a charge (depreciation) for usage. The second role of properties to a company is as a financial asset. This applies principally, although not exclusively, to freehold property".

However, the financial state of these companies and their assets are reflected in their balance sheets. Balance sheet is an invitation to the general public, particularly investors, to partake in the business of the company; although, companies record property either at current value or historic cost in their balance sheets. It is important for valuers, again, to note that if majority of companies adopt the latter approach then the contribution of property to asset value could be significantly under - reported. Necessary adjustments have to be made in the valuation for it to reflect accurately the existing use value of a business enterprise. But, either way, property is recognized as a substantial asset or a high operating cost for many companies (Wyatt, 2001).

For example, the two main areas of weakness are income measurement (especially in terms of general price changes), and property asset valuation (whether general prices are changing or not). This is so because accounting practices are based roughly on five broad principles, according to Aluko (2000), as follows:

(a) The stated value of asset not held for resale should be based on their cost regardless of their market price.

(b) The stated value of assets held for resale should be based on their cost or market price whichever is lower.

(c) A mere rise in market price is not a profit, but if the asset is held for resale, a mere decline in market price is a loss.

(d) Nothing can bring profits except what has been sold.

(e) In general, under - statement is "conservative" and commendable; over - statement is dishonest and reprehensive.

These principles often give rise to figures, which are out of line with facts, therefore, valuers have to be cautious in interpreting the figures in the balance sheet in valuation of property asset for unitisation and securitisation.

\section{Capital market and property valuation}

The capital market is the framework of institution that arrange for long-term financial assets such as shares, debenture stock and mortgage. Within this framework are primary market institutions such as issuing houses and secondary market institutions like the stock exchange. In Nigeria, at the apex of the capital market are the securities and exchange commissions followed by Nigerian Stock Exchange. 
Table 2. Prices of selected privatized enterprises as at $31^{\mathrm{ST}}$ December 2002

\begin{tabular}{|c|c|c|c|c|c|}
\hline PRIVATIZED COMPANY & $\begin{array}{l}\text { DATE OF } \\
\text { OFFER }\end{array}$ & $\begin{array}{c}\text { OFFER } \\
\text { PRICE (N) }\end{array}$ & $\begin{array}{c}\text { MARKET PRICE } \\
\text { AS AT 31/12/02 (N) }\end{array}$ & $\begin{array}{c}\% \\
\text { CHANGE }\end{array}$ & $\begin{array}{c}\text { CAPITAL } \\
\text { APPRECIATION }\end{array}$ \\
\hline & (1) & (2) & (3) & (4) & $(5)=(3)-(2)$ \\
\hline National Oil Plc & $8 / 5 / 89$ & 2.0 & 24.80 & 1140.00 & 22.80 \\
\hline Unipetrol Nig. Plc & $27 / 5 / 91$ & 2.0 & 28.38 & 1319.00 & 26.38 \\
\hline UNIC Ins. Plc & $24 / 7 / 89$ & 1.2 & 2.35 & 95.83 & 1.15 \\
\hline Crusader Ins. Plc & $6 / 11 / 89$ & 1.3 & 2.71 & 108.46 & 1.41 \\
\hline Niger Ins. Plc & $6 / 11 / 89$ & 1.3 & 4.67 & 259.23 & 3.37 \\
\hline WAPIC Ins. Plc & $6 / 11 / 89$ & 1.1 & 0.72 & -34.55 & $-0,38$ \\
\hline BAICO Plc & $6 / 11 / 89$ & 1.1 & 0.71 & -35.45 & -0.39 \\
\hline Ashaka Cement Co. Plc & $5 / 3 / 90$ & 1.2 & 6.88 & 473.33 & 5.68 \\
\hline Benue Cement Co. Plc & $20 / 8 / 90$ & 0.9 & 4.79 & 432.22 & 3.89 \\
\hline Flour Mills Nig. Plc & $30 / 1 / 89$ & 0.8 & 8.00 & 900.00 & 7.20 \\
\hline NIYAMCO Nig. Plc & $12 / 2 / 90$ & 0.7 & 3.49 & 398.57 & 2.79 \\
\hline Okomu Oil Mills & 2/7/90 & 0.9 & 10.00 & 1011.00 & 9.10 \\
\hline AIICO Ins. Plc & $6 / 11 / 89$ & 1.65 & 3.75 & 127.27 & 2.10 \\
\hline Guinea Ins. Plc & $6 / 11 / 89$ & 0.8 & 0.66 & -17.50 & -0.14 \\
\hline NEM Ins. Plc & $6 / 11 / 89$ & 1.15 & 0.62 & -46.09 & -0.53 \\
\hline Prestige Assurance Plc & $3 / 10 / 89$ & 1.15 & 3.80 & 230.43 & 2.65 \\
\hline Royal Exchange & $3 / 10 / 89$ & 1.75 & 2.91 & 66.29 & 1.16 \\
\hline Sun Ins. Plc & $3 / 10 / 89$ & 1.25 & 0.50 & -60.00 & -0.75 \\
\hline Afribank Nig. Plc & $11 / 1 / 93$ & 1.2 & 5.48 & 356.67 & 4.28 \\
\hline First Bank Plc & $6 / 11 / 92$ & 2.0 & 17.00 & 750.00 & 15.00 \\
\hline FSB International Bank Plc & $24 / 5 / 92$ & 0.7 & 3.50 & 400.00 & 2.80 \\
\hline IMB Plc & $21 / 12 / 92$ & 0.95 & 0.81 & -14.74 & -0.14 \\
\hline NAL Merchant Bank Plc & $8 / 10 / 92$ & 3.0 & 2.40 & -20.00 & -0.60 \\
\hline Savannah Bank Plc & $4 / 1 / 93$ & 1.0 & 1.32 & 32.00 & 0.32 \\
\hline UBA Plc & $10 / 5 / 93$ & 1.8 & 19.00 & 955.56 & 17.20 \\
\hline Union Bank Plc & $7 / 12 / 92$ & 1.0 & 15.60 & 1460.00 & 14.60 \\
\hline Cement Co. Of Northern Nigeria Plc & 2/3/92 & 1.0 & 2.32 & 132.00 & 1.32 \\
\hline Impresit Bakolori Plc & $6 / 1 / 92$ & 0.7 & 2.82 & 302.86 & 2.12 \\
\hline National Salt Plc & $11 / 12 / 91$ & 0.7 & 2.84 & 305.71 & 2.14 \\
\hline Aba Textile Plc & $14 / 10 / 91$ & 0.75 & 1.46 & 94.67 & 0.71 \\
\hline Union Dicon Salt Plc & $14 / 1 / 93$ & 2.0 & 19.8 & 875.00 & 17.50 \\
\hline
\end{tabular}

Source: The Nigerian Stock Exchange

\section{The Nigerian Stock Exchange}

The Nigerian stock exchange is a place like a market where people buy and sell stock and shares. The exchange was incorporated on September 15, 1960 and, commenced business on June 5, 1961. In December 1977, it became The Nigerian Stock Exchange, with branches established in different part of the country. The exchange, which started with only 19 securities traded on its floors in 1961, now has 260 securities made up of 17 government stocks/bonds, 49 industrial loans (debenture)/preference stocks and equity/ordinary shares of companies all with a total market capitalisation approximately N620 billion as at September 24, 2001. Most of the listed companies have foreign/multinational affiliations and represent a profile of the various sectors of the economy, ranging from automobile, banking, airlines, breweries, through pharmaceutical to agro-allied, published, textile, petroleum and insurance companies.

Without a secondary market medium, there would be no readily available means for stock purchases to resell or buy their securities or where companies can raise capital. If a stock exchange did not exist, or shares were not listed on the exchange, an investor desiring to sell shares would be left to finding a buyer on his or her own, or finding a stockbroker willing to invest the time and energy to seek out a buyer. Thus, stock exchange furnishes continuous information to dealing members and, also, assists in the effective allocation of resources.

As noted, government privitisation programmes have primarily driven the growth of stock exchange in the country. And, given that all factors of production collapsed in a one-factor perspective into capital, all factors (including real estate) are financial assets. The value of a business enterprise particularly for those publicly quoted, are better revealed at the capital market or stock exchanges. A business property appraisal is thus taken to refer to an appraisal of the worth of a business property asset (rather than an investment property asset) on behalf of an occupier (rather than an investor). It is a worth concept for property that contributes to the profitability of a business. A business property appraisal is specific to the business occupier because it utilises client specific information (Wyatt, 2001). 
From the foregoing, and by implication, privitisation is a further way of securitising the factors of production including real estate employed by a company. Thus, evidence from table 2 can be utilised to illustrate the impact of operations of stock exchange to property advice. For example, the table indicates that most of the privitised companies had witnessed at least twofold increase in their market prices; an indication of favourable public perception of these companies since privitisation. Such investor's perception is largely predicted on corporate performance, which improved in many of these companies. The table shows that Union Bank Plc recorded the highest price movements of 1400 percent from an offer price of N1.00 in 1992 to N15.60 on December 31, 2002, thus generating a high capital appreciation (gain) of N14.60 per share. Unipetrol, African Petroleum, Union Dicon Salt followed in descending order. Except Sun Insurance and BAICO, which recorded negative growth rates, all the remaining privitised companies recorded substantial price gains since listing in The Exchange.

An assessment of the market capitilisation showed that the privitised companies had by $31^{\text {st }}$ December 2002 collectively registered a post-privitisation market capitilisation of N117 billion, as against N4 billion at the time of capitilisation. This indicates a growth of 2825 percent. The 28 companies, which were listed for the first time as a result of the divestment exercise, recorded a post-privitisation growth of 1630 percent from a market capitilisation of $\mathrm{N} 2.7$ billion at the time of initial offering to N46.7 billion at the end of December 2002. As was expected, the debt to equity ratio of many of the companies dropped following privitisation. In fact, only four or twelve percent of the affected companies recorded a higher post-privitisation leverage.

As recorded above, therefore, securitisation of assets by privitisation has improved market awareness in Nigeria, as the capital market was the preferred vehicle for disinvestment to ensure widespread shareownership. The level of awareness may be measured by the level of subscription to the offers. Of the 28 new companies listed, 16 were either fully or oversubscribed. This has several implications on property valuation advice for unitisation and securitisation as follows:

\section{Efficient Market Information}

The emergence of the passive business owners of real estate securities (property shares or unit trusts) has began to render inadequate those valuation reports that merely render an opinion of value. The reason for this is not far-fetched; passive absentee owners require more information than the traditional investor-local lender. This is partly because the absentee owner is not familiar with trends in the local area in which the property is located, and real estate investments are uniquely sensitive to local trends. For estate surveyors and valuers to operate effectively under this situation, the property market must be as efficient as the capital or stock market. But, the commodities traded in real estate market in Nigeria are heterogeneous in nature, with large-lot size, lumpy, illiquid and indivisible. Besides, property has no central market place and the details of many transactions are not made publicly available. Consequently, traditional valuation reports do not address many very relevant issues. Rather, the traditional valuation provides a picture of the property as of the date of valuation. This is a static analysis and, not forward-looking. The quality of valuation advice in respect of securities and trusts depends on the full integration of real estate market into global investment portfolio. This requires full understanding of property investment characteristics and how those methodologies that operate in other investment media can be integrated into real estate market.

\section{Investment advice}

The growth of property traded securities and unit trusts will require investment advice from valuers as the financial characteristics of property have changed. Property valuation is no longer brick and mortar valuation including planning details but, rather, investment analysis; a counterpart to security analysis. Therefore, the demand now is for objective advice which places property in the context of the wider economy and which uses the vocabulary and analytical techniques of other markets. In order to evaluate investment alternatives, investors must be able to compare the financial position and profitability of each alternative. Valuers and Property analysts need to be able to develop such awareness for three reasons:

1. The return on other investment may be a measure against which a property investment should be appraised.

2. The return on other investments may be a guide to the future value of property.

3. Subject to (1) above, the return on other investments may be a guide to the implied necessary future performance of property.

Nonetheless, investors require a common denominator such as property indices and uniform standards for income measurement and asset valuation to perform 
such comparative analyses. For instance, various indices are now being published in advanced countries by organizations, like Driver Jonas, Investment Properties Databank Ltd. (IPD) and the WM Company Ltd. in U.K., which depict the performance of the property market. This is absent in Nigeria and, therefore, fund managers and investment advisers are faced with several potential yardsticks with which to compare property investment performance. Three broad levels of performance analysis can be identified: the portfolio, individual property and also other researched areas (Morrell, 1991; 1994). A primary objective of performance analysis at the portfolio level is to measure the effectiveness of investment decisions and portfolio management activities. Performance evaluation of property shares and units can therefore help to assess the following:

1) the effect of being over-or under-exposed, relative to a benchmark, in certain sub-sectors of the market, such as a use sector in a particular areas;

2) the levels and sources of variability in returns;

3) the stock selection ability of the organisation;

4) the impact of carrying out developments or refurbishment;

5) the effect of releasing marriage value by merging interests in land; and;

6) the impact of other transactions net of costs.

However, the imperfections of the property market have enormous implications for index construction. Real estate has been traditionally regarded as a lumpy, heterogeneous, indivisible and illiquid investment. In addition, while data on market trends is more freely available, information on individual property transactions and values remain secret. The absence of a centralised market place also means that comprehensive data on property performance is difficult and costly to collect.

Another possible cause of difficulty in property index construction is the accuracy of valuations prepared by estate surveyors and valuers in the country. Equity market returns can be calculated from dividends and prices actually paid in the market. By contrast, property returns are deduced mainly from rental income and from valuations. Inaccurate and inconsistency in valuations, which relate to the practice and timing of property valuation, to the statistical qualities of the resulting performance index, and also to the interpretation of and confidence in the results create fundamental difficulties for the construction of property performance indices and investment performance analysis. Potential differences may exist between valuation and actual sale price of same property or valuations prepared by one firm may not act as a good proxy for valuation prepared by another in respect of the same property. In Nigeria here, the credibility problem was highlighted in the July, 1988 edition of the Nigerian Institution of Estate Surveyors and Valuers (NIESV) Journal and during the workshop on valuation of special enterprise organised by Chuzytech Resources Limited in collaboration with the Estate Surveyors and Valuers registration Board of Nigeria (ESVARBON), a regulatory body for property valuation practice, in September 1999. One major conclusion the two pertinent papers in the journal Aluko (1998) and Ogunba and Ajayi (1998) came to is that valuation depends so much on valuers' interpretation of market information that there is no escaping the subjectivity that characterises the process. This view is corroborated in Ratcliff (1975), Downs (1991), Hager and Lord (1985), Brown (1985; 1992), and Lizieri and Venmore-Rowland (1991) as cited in Aluko (1998). However, part of the problem, it is acknowledged arises from the valuers' conduct (Aluko, 2000), over reliance on traditional methods and undue bias towards clients.

In addition to the above, a stock exchange does not ipso facto provide or ensure liquidity necessary for efficient market system. It would be non sequitur to conclude that, because an exchange exists and securities are listed thereon, there will always or even usually be ready and willing buyers whenever there are ready and willing sellers of securities. A stock exchange is by far the best opportunity for liquidity to occur, but an exchange is not a guarantee of liquidity and an avenue for proper investment analysis and advice. The lack of significant numbers of listed property companies is a major cause of the paucity of daily trading and the concomitant lack of liquidity within the stock markets. The two fundamental questions of (i) how to attract more listings, especially from privately-owned property companies, and (ii) how to develop greater public interest and participation in stock trading are inextricably linked. Privately held companies do not find an illiquid market attractive, and until there is a more market listings and trading, public interest is difficult to develop. Thus, valuation of property shares and unit or investment trusts become difficult.

The need for uniformity in income measurement and asset valuation, as earlier explained, between valuers and accountants is equally directly germane to the quality of investment advice offered investors by valuers. Again, balance sheet is the company's invitation to the financial market to participate in the 
profit. To be sure, investors would prefer an invitation in the form of a forwardlooking valuation of the firm/ company as a whole. Perhaps, with Uniform Asset Valuation Standards as guidance for valuers and accountants, quality valuation practice of tradable securities belonging to property companies will be ensured. In Nigeria, there is no uniform standard prepared for both accountants and valuers in the country. Besides, the 1985 Property Valuation Standards Manual prepared by The Nigerian Institution of Estate Surveyors and Valuers is outmoded and inadequate for meeting the challenges and opportunities provided in the valuation of property securities and trusts in the country. Also, the adoption of the U.K. valuation standard as set out in the Appraisal and Valuation Manual (RISC, 2000), colloquially known as the "Red Book" is good, but, it has become prescriptive and U.K.-specific and has no relevance to the economic climate in the country. Usually, the Securities and Exchange Commission requires all firms with publicly traded debt or equity securities to apply these standards to their financial statements.

\section{Valuation concerns}

Perhaps, the most misunderstood issue surrounding property securities (shares) and unit trusts is the valuation. Much of the controversy stems from the inability to recognise property as an integral factor in many business decisions and, the need for property advice to be set in a business context. In addition, many also assert that valuers do not have a role to play in the valuation of an overall property share or trust or its units. But, it should be noted that they do have a real role to play in providing (Richard Ellis, 1998):

- Initial expert advice regarding property acquisitions to ensure that property fundamentals are not forgotten in the rate to invest funds;

- Periodic valuations to monitor the performance of the property and the asset management regime;

- Valuation advice to assist new capital raisings;

- Advice on value preservation and value adding strategies such as extensions and refurbishment;

- Rent review advice; and,

- Formulating existing strategies.

Also, at the portfolio or company level, strategic property advice requires an understanding of and organization's business plan in order to estimate property requirements and identify where value can be added. Examples of strategic property advice, according to Wyatt (2001), include:

- review and reduction of property operating costs;
- $\quad$ portfolio reviews (after a merger or take-over for example);

- due diligence on proposed investments, including mergers, acquisitions and,

- advice on financing options and the handling of property in the corporate balance sheet;

- $\quad$ project management of divestment company;

- business appraisals and development of business plan; and,

- feasibility studies

With the foregoing in view and for property valuation to meet the needs of business occupiers and investors, there is the need for adoption of forward-looking investment analyses and performance measurement techniques utilized in other asset markets. Several reasons can be advanced for this. Firstly, the increasing interest in property investments by institutional investors has subjected it to comparative analysis. Secondly, the depression in the sector and its consequential effect on returns has resorted into investors reappraising their investments and investment advice. Thirdly, there is an increasing attention being paid to analysis of property transactions and performance from investment analysts, such as stockbrokers and analysts, trying to appraise property investments. Against this background, valuers must note the increasing awareness by clients of their rights and, remember that as property experts their judgements must be equal to that of fund managers in respect of property matters. It is also necessary to acknowledge that property expertise must in today's investment environment be specifically balanced against broad economic data (Richard Ellis, 1998).

Property advice in respect of property shares and unit trusts can be at two levels - individual and company/ portfolio levels. They are as follows:

\section{Individual/Property Shares or Unit Trusts}

Three factors are specific to an investment, which affect its value. These are risk, income growth and depreciation (or income loss). Any valuation or investment analysis of a property share/unit trust will consider these factors, whether implicitly or explicitly. Nevertheless, the most important impact on valuers is the need to place greater reliance on Discounted Cash Flows (DCF) and its variants - Net Present Value (NPV) and Internal Rate of Return (IRR) rather than on the capitalisation of first years' income approach. This in turn requires a more forward-looking approach 
supported by quality market intelligence and research.

As property valuation is now more akin to investment analysis, DCF techniques are an important aid in the evaluation of investment proposals relating to property shares and unit trusts. The overriding advantage of the DCF techniques is that they recognise the time value of money. With this approach, valuation becomes more comparative and, is, therefore, placed alongside other investments. Discounting the actual and projected cash flows at the total rate of return required for property is the approach by which local and overseas funds are investing. Alcock (1999) comment as follows:

Valuers should also remember that DCF's are used by many other disciplines, for example, Share Analysts, Township Developers, Banks and so on. As valuers, you cannot afford to be left behind. A Township Developer, for example, makes projections on; sales tempo, sales prices, escalation in prices, service costs, escalation in costs, etc. so why should valuers of investment property be any different? The answer of course is that they shouldn't.

The method gives the total rate of return (income and capital), the best benchmark currently available, by which property, equities and gilts can be compared. In the DCF techniques the following projections are given consideration - the discount rate, rental growth, outgoings, vacancies, management fees, letting commission, capital works, terminal value, etc. Consequently, they are useful in determining the investment worth or value of the property shares or unit trusts.

The current climate in the real estate industry suggests that valuers should be more concern in the ability of real property to generate cash flow. Particularly troublesome aspects of this issue are estimating absorption rates for new or recently renovated space and possible adverse future changes in local supply and demand. Thus, it is important that valuation reports emphasize present and future profitability of a real estate investment and full disclosure of circumstances that could materially affect the financial integrity of the investment. For example, since valuation is a snapshot in time, the estimate of price in the market today (OMV) will not necessarily be the same as it will be at some future date. In the context of bank lending, such a difference in time may have a significant impact on the lending decision. The banks do not want just a valuation of the price today, but also require an indication of the likely future-selling price. Banks, therefore, asks valuer to give in addition to OMV, the estimated restricted realization price (ERRP), the estimated and realization price (ERP), which moves the marketing period, as assumed in $\mathrm{OMV}$, from prior to the valuation date to a reasonable period running from it. While an OMV could be appropriate to update a company's asset value, ERP and ERRP now offers the use of a more relevant figure for cash flow projections of property shares/trusts being used as collateral for bank credit. The method is not without its drawbacks, but, with recent developments, it is the most useful for the situation at hand.

\section{Company/Portfolio Level}

It is important to note that property advice to investors in property shares/trusts needs to be linked to the core functions of the business and valuers need to appreciate the implications that property has for business processes. In the valuation of property company's portfolio, the following financial statements are important: the profit and loss account, the balance sheet, notes to the accounts, current cost accounts, a statement of source and implications of funds and a statement of valueadded.

The balance sheet and the profit and loss account are the main statements of the financial situation of the company. While the balance sheet is a snapshot of the health of the company at a particular point in time, the profit and loss account is one indication of the changes to the balance sheet over the year of trading. As it is being done, property appears in both the profit and loss accounts as a cost (rent for leaseholds, depreciation for freeholds) and as an asset on the balance sheet. In addition, the notes to the accounts include details of future commitments that relate to operating leases. Property can therefore have two impacts upon the perceived performance of portfolio of a property company. Investors are guided by the position of the company as declared in the company accounts (Nelson et al, 2000), whilst the underlying performance of the company will remain unchanged; the way in which information is presented impacts on the reader's perception of the company's performance as disclosed in the accounts. Valuers should note whether the figures in the accounts are reported at their current value or historic costs and, make appropriate adjustments. The value of holding property to business needs to be measured against the return, which that equity could achieve elsewhere. Analysts of property investment/development companies strive to calculate the current net asset value of each company by updating the balance sheet values. This is the value of the assets to the profitability of the company on a going concern basis or, in a nutshell, the value-in-use. 
Value-in-use is an appraisal of business worth of an asset, often calculated using a DCF approach. In practice, Depreciated Replacement Cost (DRC) approach is adopted, although, it is subject to the test of adequate potential profit.

In effect, valuers have to subject the valuation to profitability measures using trading profit as a percentage of turnover, profit before or after tax, earnings per share, dividend per share, number of times covered and assets per share. For example, in contrast, the property developer/trader has lower levels of asset backing, and the shares tend to stand at a premium to net annual value (NAV). These companies are profit generators and their valuation is based more on profits than on assets. A price earnings ratio (PER) is applied to the company's forecast earnings per share to derive a price. The size of the PER depends largely on the market's expectation for after-tax profit growth. These companies tend to have lower market capitalisations than the property investment/ development companies, as it becomes increasingly harder to maintain consistent levels of profit growth as the company gets larger (Adams and VenmoreRowland, 1990; Isaac, 1998). Also, quoted companies have their shares determined by supply and demand on the stock market, and they normally trade at a discount to NAV. From the foregoing, it is also necessary that valuers employ relevant accounting ratios in valuing property companies so as to establish their return on investment, liquidity and cash flows, cost of capital and an optimal capital structure for a particular company. A business property appraisal is thus taken to refer to an appraisal of the wroth of a business property asset (rather than an investment property asset) on behalf of an occupier (rather than an investor).

\section{Conclusions}

The paper has attempted to inquire into the valuation implications of property tradeable securities. We have found out that property investments cannot be appraised in isolation. And, that property valuation has to be comparative in outlook as it is more akin to investment analysis. It is also noted that property valuation judgements must match that of fund managers in respect of property matters. Thus, property market has to be as efficient as the capital market. The implications of the foregoing are to farfetched and needs to be addressed, as indicated below, in order to improve the quality of property advice for business valuation of property companies.

(a) The absence of sufficient market data transactions of a truly comparable nature makes pricing somewhat difficult and subjective. There is therefore clearly a need for improvement in the recording and availability of transaction data. The development of historical data series (price indices) and centralised/database by property valuation firms and property companies to allow forecasting at national, regional and local market/ city levels by sector is suggested in the country; the type that is comparable to the Drivers Jonas/ Investment Property Databank Limited (IPD) Ltd. and WM Company Limited (WM Ltd.) in the united Kingdom. Thus, the secrecy and confidential nature of property transactions have to be relaxed to allow a comprehensive data to be collated and analysed.

(b) There is also the need for development of standards and regulatory framework for valuation of property companies. Securitisation and unitization requires consistent standards in reporting on the operations of a venture because absentee owners and lenders need reliable, comparable, and consistent information concerning the status of their investments. The valuation and accounting professions in the country now faces the challenge to jointly set up a committee to formulate standards and guidance notes on asset valuation. The standards and guidance notes should be published with detailed articles explaining the reasons why certain actions had been taken and the philosophy behind those standards. Members of the valuation profession should also be encouraged to embrace the standards and guideline without being forced to do so; for, if we do not learn to control the activities of members internally, then, someone else will do it for us.

(c) The valuers have to reflect in the valuation reports of property assets of a company, the market value, market price, worth or investment value as well as DCF exercises where forecasting techniques and accounting are fully developed to allow clients take appropriate decision of whether or not to sell or buy in the property market. This will ensure codification of good practice, promote the credibility of valuers and promote their clientele base as a result of improved quality of valuation or pricing.

(d) The separation of valuation from agency functions, which is commonplace in most estate surveying and valuation firms in Nigeria is not conducive to improving the accuracy of property valuations. It should be recognised that real estate valuation is an essential cog in the marketing of 
real estate. Making information available to valuers is a necessary overhead cost of their marketing process. A properly informed valuation will "make" their deal, not break it.

And, directly relevant to the above is the need to make the Nigerian Stock Exchange much more efficient to aid accurate property portfolio analysis. Amongst the principal measures that could assist in confidence building are:

(i) Cross-listing securities on exchanges

(ii) Adoption of "merit review" standards by securities agencies.

(iii) Increasing the enforcement authority of government agencies.

(iv) Committing to public education as a primary goal of the public sector.

(v) Increasing media understanding and reporting on business matters;

(vi) Enlarging the capacity for institutional investing by pension and retirement funds;

(vii) Encouraging issuance of preferred shares and corporate notes by private companies; and

(viii)Eliminating the second-tier labeling of listed property tradeable securities

(e) Finally, the discussions above call for an improvement in the education and training of estate surveyors and valuers in the country. We need investment - based valuation surveyors to carry out investment analysis of portfolio of Property Company. Their training must include the context of other investment markets, the links between the economy and the property market which drive returns; an understanding of the risk, forecasting and depreciation; and the manipulation of this information in explicit cashflow models and portfolio models.

\section{References}

Adams A. T. and Venmore-Rowland, P. (1990) "Property Share Valuation", Journal of Valuation, Vol. 8, p. 126142.

Alcock, D. (1999) "The Relevance of Capitalisation Rates in the Current Property Market". In: An Insight into Listed Property Trust in Australia and the USA Greg Paramor, Paladin, Australia, May, 5 p.

Aluko, B. T. (1998) "Property Valuation: Are Estate Surveyors and Valuers Interpreters or Creators of Value?" The Estate Surveyor and Valuer, Vol. 21, No. 2 July, p. 9-17.

Aluko, B. T. (2000) “A Study of the Appropriateness of Mortgage Valuation for Institutional Lending in Nigeria", an unpublished Ph.D Thesis, Obafemi Awolowo University Ile-Ife, Nigeria. 243 p.
Baum, A. and Crosby, N (1995) Property Investment Appraisal, second edition, International Thomson Business Press, London.

Brown, G. R. (1985) "Property Investment and Performance Measurement: a Reply", Property Valuation and Investment, Vol. 4, No. 1, p. 33-44.

Brown, G. R. (1992) "Valuation Accuracy: Developing the Economic Issues", Journal of Property Research, 9, p. 199-207.

Evans, M. French, N and O’Roarty, B (2001) “Accountancy and Corporate Property Management - a Briefing on Current and Proposed Provisions Relating to UK Corporate Real Estate," Property Investment and Finance, Vol. 19, No. 2, p. 211-223.

Isaac, D (1998), Property Investment, Macmillan Building and Surveying Series, London.

Lizieri, C. and Venmore-Rowland, P (1991) "Valuation Accuracy - a Contribution to the Debate", Journal of Property Research, Vol. 8, p. 116-122.

Morrell, G. D. (1991) "Property Performance Analysis and Performance Indices: a Review", Journal of Property Research, Vol. 8, p. 29-57.

Morrell, G. D. (1994) "Property Indices: a coming of age?" Property Valuation and Investment, Vol. 13, No. 3, p. $8-21$.

Nelson, T. Potter, T. and Wilde, H (2000) "Real Estate Assets on Corporate Balance Sheets", Journal of Corporate Real Estate, Vol. 2, No. 1, p. 29-40.

Ogunba, O.A. and Ajayi, C.A. (1998) “An Assessment of the Accuracy of Valuations in the Residential Property Market of Lagos," The Estate Surveyor and Valuer, Vol. 21, No. 2 July, p. 19-23.

Richard Ellis (1998) "Challenges in the Commercial Sector - A Valuer's View" AIVLE National Property Conference - Canberra. 13 p.

RICS (2000), Valuation and Appraisal Manual, RICS, London.

Wyatt, P. (2001) "An Investigation of the Nature of the Valuation Service Offered by Business Occupiers" Journal of Property Investment and Finance, Vol. 19, No. 2, p. 100-126. 